\title{
Immediate Response of Human Dental Pulp Capped with Mineral Trioxide Aggregate, Portland Cement and Biodentin
}

\author{
Bashar $\mathrm{AKM}^{1 *}$, Kabir $\mathrm{AKMN}^{2}$, Rizdina RA ${ }^{3}$, Shikder $\mathrm{AHMZH}^{4}$, Ghosh $\mathrm{R}^{5,}$ Rahman $\mathrm{MM}^{6}$ \\ ${ }^{I}$ Department of Conservative Dentistry \& Endodontics, Bangabandhu Sheikh Mujib Medical University, \\ Dhaka, Bangladesh; ${ }^{2}$ Department of Pathology, Bangabandhu Sheikh Mujib Medical University, Dhaka, \\ Bangladesh; ${ }^{3}$ DPHI, Bangabandhu Sheikh Mujib Medical University, Dhaka, Bangladesh; ${ }^{4}$ Department \\ of Pedodontics, Bangabandhu Sheikh Mujib Medical University, Dhaka, Bangladesh; ${ }^{5}$ Department of \\ Orthodontics, Bangabandhu Sheikh Mujib Medical University, Dhaka, Bangladesh; ${ }^{6}$ Department of \\ Pathology, Dhaka Medical College, Dhaka, Bangladesh
}

\begin{abstract}
Background: The initial inflammatory reaction of pulp capping materials on the dental pulp has an intimate relation in promoting the future cellular differentiation and biomaterial mineralization. So, analysis of immediate pulpal tissue reaction in vivo, is also important for evaluation of ultimate efficacy any pulp capping agent. To observe immediate inflammatory response of Human Dental Pulp capped with Mineral Trioxide Aggregate (MTA), Biodentin and Portland Cement (PC).
\end{abstract}

Methods: A total of 70 permanent premolars teeth planned to be extracted for orthodontic alignment of occlusion were used as study sample. The teeth were divided into 3 experimental groups, MTA $(n=20)$, Biodentin ( $\mathrm{n}=20)$ Portland cement $(\mathrm{n}=20)$ and control group $(\mathrm{n}=10)$. After having an occlusal exposure of approximately $1.5 \mathrm{~mm}$ in diameter; in group A, pulp of teeth was capped with 2-mm-thick layer of ProRoot White MTA (Dentsply) and in group B, with sterile Biodentin (Septodont) according to the manufacturer's recommendations. Whereas in group C, pulp of teeth was capped with sterile Portland Cement (PC). After placing the experimental material in each group, all teeth restored with glass ionomer cement. After 24 hours the teeth were extracted, fixed in $10 \%$ buffered formalin solution, then decalcified by $10 \%$ nitric acid and embedded in paraffin. Finally, sectioned into 2 to 3 -micron-thick serial sections in the linguo-buccal plane and stained with hematoxylin-eosin. After then the amount of pulp inflammation (type, intensity, and extension) were determined by using a predetermined evaluation criterion under an optical microscope at $40 \times$ magnification. Ten intact teeth, which received no exposure and pulp capping but extracted due to orthodontic purpose were also collected and treated as the control group (group D); undergone same histologic preparation and evaluation. Significantstatistical differences among the experimental groups were to be found $(p<0.05)$.

Results: Histologically, all the three tested materials produced immediate pulpal tissue reaction. 'Biodentin' found to be most immediate pulpal tissue reactive (reactive in $100 \%$ cases) and 'Portland Cement' showed least immediate tissue reaction (only in $30.0 \%$ cases). whereas, MTA produced immediate tissue reaction only in $50.0 \%$ cases. Immediate pulpal inflammatory reaction in response to tested material found to be statistically significant different between 'Biodentin' and 'Portland cement' $(p=0.01)$, also between 'Biodentin' and 'MTA' and $(p=0.001)$; but there was no statistically significant difference between 'MTA' and 'Portland cement' $(p=0.197)$.

Conclusion: Considering the maximum immediate pulpal tissue reaction (Inflammation), Biodentin is expected to produce most favorable ultimate bioactivity (biomaterial mineralization) after pulp capping.

Keyword: Human dental pulp, capping, MTA, Portland cement.

\section{Introduction}

The application of biocompatible materials on exposed pulp protects the pulp-dentin complex

*Correspondence: AKM Bashar, Department of Conservative Dentistry \& Endodontics, Bangabandhu Sheikh Mujib Medical University, Dhaka, Bangladesh; email:drbasharakm@gmail.com against chemical irritation from the bacterial substrate,from the toxicity of the material used and finally new bacterial penetration due to microleakage ${ }^{1-4}$ Calcium hydroxide had long been used for this purpose but because of the resultant incomplete dentin bridge with tunnel defects that somtimes lead to the failure of pulp capping,there 
had been a long search for appropriate bioinductive material. ${ }^{5,6}$ Mineral Trioxide Aggregate (MTA), primarily comprises tricalcium silicate $\left(\mathrm{C}_{3} \mathrm{~S}\right)$, tricalcium aluminate $\left(\mathrm{C}_{3} \mathrm{~A}\right)$, tetracalciumaluminoferrite $\left(\mathrm{C}_{4} \mathrm{AF}\right)$, and bismuth oxide $\left(\mathrm{Bi}_{2} \mathrm{O}_{3}\right)$, has been developed and reported for good sealing abilityand tissue healing. ${ }^{6-12}$ Bridgelike dentin was observed in cases of pulp capping by MTA. ${ }^{11-14}$ MTA is moisture-insensitive, can induce proliferation of fibroblasts and mineralization of osteoblasts, and seems to be biocompatible. ${ }^{6,15,16}$ However, MTA is reportedly difficult to use because of its long setting time, poor handling properties, high material costs, and the discoloration potential of dental tissue. ${ }^{5,6,8,14}$

Camilleri $\mathrm{J}$ reported that MTA and Portland cement (PC) seem almost identical macroscopically, microscopically, and by $\mathrm{x}$-ray diffraction analysis. ${ }^{17}$ Portland cements, is a fine powder composed of $65 \%$ lime, $20 \%$ silica, $10 \%$ alumina and ferric oxide and 5\% other compounds, same chemical elements as MTA. ${ }^{18-20}$ PC differs from MTA that potassium ions come from the minor oxide constituent provides an additional source of hydroxyl ions. ${ }^{18,19}$ Portland cement don't have bismuth oxide, which in MTA increases its radiopacity. ${ }^{18}$ The potential applications of PC on pulp therapy have already been explored that no sign of pulp cell damage could be identified after placing PC into animal and human pulp as pulp capping material. ${ }^{21} \mathrm{PC}$ stimulates the expression of mRNAs of a dentinspecific protein and a non-collagenous protein involved in mineralization in cultured human pulp cells. $^{22}$ Its antibacterial effect is comparable to MTA and biocompatible to human pulp cells when used as pulp capping materials. ${ }^{22} \mathrm{PC}$ also promotes the precipitation of bone like hydroxyapatite and dentin bridge formation. ${ }^{23}$

Biodentine (Septodont, Saint Maur des Fosses, France), is a new calcium silicate based restorative cement with dentin-like mechanical properties, consists of mainly tricalcium and dicalcium silicate $\left(3 \mathrm{CaO} \mathrm{SiO}_{2}\right.$ and $\left.2 \mathrm{CaO} \mathrm{SiO}_{2}\right)$ powder and calcium chloride $\left(\mathrm{CaCl}_{2}\right)$ liquid. which can be used as dentin substitute on crowns and roots similar to how MTA is used. ${ }^{3}$ It has a positive effect on vital pulp cells and stimulates tertiary dentin formation. In direct contact with vital pulp tissue, it also promotes growth, proliferation and differentiation of stem cells regenerating and consequently the formation of reparative dentin. ${ }^{2,24-26}$

There are now evidences that inflammation is a prerequisite for pulp healing. ${ }^{27,28}$ Inflammation alone initially contributes to the repair process of healing, though after initiation of this process bioactive molecules are essential in the formation of reparative dentin. ${ }^{28}$ Depending on the form and severity of the inflammatory processes, and according to the capping agent, pulp reactions are induced specifically. ${ }^{23}$ Immunocompetent cells are recruited in the apical part. They slide along the root and migrate toward the crown. ${ }^{28}$ Due to the high alkalinity of the capping agent, pulp cells display inflammation, proliferate, and increase in number and size and initiate mineralization. ${ }^{29}$ Thus inflammatory processes contribute to produce a reparative dentinal bridge closing the pulp exposure. ${ }^{30}$ But in any case, the degree of inflammatory reaction appears dependent on the bioactive molecule under investigation. ${ }^{28}$ So understanding the initial inflammatory pulpal tissue reaction, as produced by any pulp capping material, helps to get an idea of its ultimate bioactivity.

MTA, portland cement and Biodentin all three are calcium silicate based material but they differ among them by some chemical component; and it is important to note that changes in the chemical components of any material may alter its physical and possibly its bioactive properties. While the link between the initial inflammation and cell commitment is not yet well established but appears as a potential key factorin the reparative process. ${ }^{28}$ That's why present in vivo study had been carried out to observe the immediate pulpal reaction when MTA, Biodentine or PC is used for direct pulp capping; so as to guess an idea regarding it's ultimate bioactivity or to link with their ultimate capability of hard tissue genesis.

\section{Materials and Methods}

Present prospectiveclinical study was carried out in the Department of Conservative Dentistry \& Endodontics together with the Department of Orthodontia, Bangabandhu Sheikh Mujib Medical University (BSMMU), Dhaka, Bangladesh during the period of 2015-2017. Based on previous studypurposeful sampling method was applied to for sample collection and ultimately a total of seventy (70) intact human maxillary and 
mandibular premolars with clinically normal pulps, with closed apex, no caries either clinically or radiographically, and without any restoration; and with no periodontal involvement those were scheduled for extraction for orthodontic reasons were selected from patients ranging in age from 15-20 years having no systemic disease. ${ }^{4,25,28,31}$ Subjects were treated in accordance with the Helsinki declaration. Patients received thorough explanations concerning the experimental rationale, clinical procedures, and possible complications of the procedure. All experimental procedures were reviewed and approved by the Ethical Committee, BSMMU (approval number BSMMU/2015/8088 date 22-06-2015)

Operative Procedure: Under local anesthesia, occlusal Class I cavities were prepared by using round sterile diamond burs at high speed with airdistillated water spray coolant. An exposure of pulp, approximately $1.5 \mathrm{~mm}$ in diameter was made with round carbide burs $(1.5 \mathrm{~mm})$ under air distillated water-cooling. New burs were used during each preparation. Bleeding was controlled with saline irrigation, and a sterile cotton pellet pack placing onto the pulp exposure sites. The teeth were divided into 3 experimental groups, MTA $(n=20)$, Biodentine $(n=20)$ or Portland cement $(n=20)$ and 1 control group $(n=10)$.

In group A, pulps of teeth were capped with 2mm-thick layer of ProRoot White MTA (Dentsply, Tulsa Dental, Tulsa, OK, USA) and in group B, pulps of teeth were capped with sterile Biodentine (Septodont, Saint Maur des Fosses, France) according to the manufacturer's recommendations (table I); Whereas in group C, pulps of teeth were capped with sterile Portland Cement (PC).

Table I: Description of the study materials

\begin{tabular}{|c|c|c|c|c|c|}
\hline Materials & Manufacturer & Presentation & Powder composition & $\begin{array}{c}\text { Liquid } \\
\text { composition }\end{array}$ & Manipulation \\
\hline $\begin{array}{l}\text { Pro Root } \\
\text { MTA }\end{array}$ & Dentsply ${ }^{\circledR}$ & Powder/liquid & $\begin{array}{l}\text { Tricalcium silicate Dicalcium } \\
\text { silicate Tricalcium aluminate } \\
\text { Calcium oxide } \\
\text { Bismuth oxide } \\
\text { Silicon dioxide } \\
\text { Aluminium oxide }\end{array}$ & Water & $\begin{array}{l}\text { Manual: powder from a } \\
\text { pouch is mixed with the } \\
\text { water supplied in micro-dose } \\
\text { ampoule onto a mixing pad } \\
\text { using spatula incrementaly } \\
\text { till all the powder become } \\
\text { wetted and turned into a thick } \\
\text { consistency }\end{array}$ \\
\hline Biodentin & Septodont ${ }^{\circledR}$ & Powder/liquid & $\begin{array}{l}\text { Tricalcium silicate Dicalcium } \\
\text { silicate Calcium carbonate } \\
\text { Zirconium oxide }\end{array}$ & $\begin{array}{c}\text { Hydrosoluble } \\
\text { polymer } \\
\text { Calcium } \\
\text { chloride }\end{array}$ & $\begin{array}{l}\text { Mechanical: powder in on } \\
\text { capsule is mixed with } 5 \text { drops } \\
\text { of liquid in the trituratorat a } \\
\text { speed of } 4000-4200 \\
\text { rotations } / \text { min. for } 30 \text { seconds }\end{array}$ \\
\hline $\begin{array}{l}\text { White } \\
\text { portland } \\
\text { cement }\end{array}$ & $\begin{array}{l}\text { UltraTech Cement } \\
\text { Ltd }\end{array}$ & Powder & $\begin{array}{l}\text { Tricalcium silicate } \\
\text { Dicalcium silicate } \\
\text { Tricalcium aluminate } \\
\text { Tetracalciumaluminoferrite } \\
\text { Sodium oxide } \\
\text { Potassium oxide } \\
\text { Calcium sulphate }\end{array}$ & Water & $\begin{array}{l}\text { Manual: powder is mixed } \\
\text { with water incrementally till } \\
\text { all the powder become } \\
\text { wetted and turned into a thick } \\
\text { consistency }\end{array}$ \\
\hline
\end{tabular}

After placing the experimental material in each group, a flat, water-moistened cotton pellet was laid directly over the material and provisionally restored the tooth with glass ionomer cement (GC inc, Japan). Ten intact teeth were selected as the control group (group IV), which were received no exposure and pulp capping. ${ }^{4,25}$ All procedures were performed by one experienced endodontist in the Department of Orthodontics.

Histologic examination: After 24 hours the experimental teeth were extracted as atraumatically as possible. After fixation for 2 weeks in $10 \%$ buffered formalin solution, the specimens were demineralized in a decalcifying solution containing $10 \%$ nitric acid and were embedded in paraffin. Now two to three micronthick serial sections of the paraffin-embedded teeth were done in the linguo-buccal plane and were stained with hematoxylin-eosin. Coded samples were used throughout the study to avoid possible bias. By using an optical microscope connected to a high-resolution camera, samples were evaluated under normal light by an experienced oral pathologist in the department of pathology, BSMMU. Immediate tissue response at the interface of the capping material i,e, pulp inflammation (type, intensity, and extension) were determined based on the modified criteria by Nowicka et al Faraco et al Medina et al and Cobanoglu at al (table II). ${ }^{25,32-34}$ 
Table II: Criteria for histologic evaluation

Histologic Evaluation Criteria

For Type of Pulp Inflammation:

Score
1
2
3
4

Criteria

no inflammation

chronic inflammation as will be defined due to presence of monocytes and lymphocytes (the primary cells of chronic inflammation)

acute and chronic inflammation as will be defined due to simultaneous presence of granulocytes, monocytes and lymphocytes. (the primary cells of acute and chronic inflammation respectively)

acute inflammation as will be defined due to presence of granulocytes namely neutrophils, eosinophils, and

basophils (the primary cells of acute inflammation).

For Intensity of Pulp Inflammation:

Score
1
2
3
4

\section{Criteria}

absent or very few inflammatory cells /HPF

mild, defined as an average of $<10$ inflammatory cells were present $/ \mathrm{HPF}$

moderate, defined as an average of 10-25 inflammatory cells were present /HPF

severe, defined as an average $>25$ inflammatory cells were present $/ \mathrm{HPF}$

For Extension of Pulp Inflammation:

\begin{tabular}{c|l}
$\begin{array}{l}\text { Score } \\
1\end{array}$ & $\begin{array}{l}\text { Criteria } \\
\text { Absent } \\
\text { mild, defined as inflammatory cells present only next to the area of pulp exposure (against which pulp capping } \\
\text { material have been placed) } \\
\text { moderate, defined as inflammatory cells observed in part of coronal pulp } \\
3\end{array}$ \\
4 & $\begin{array}{l}\text { severe, defined as all coronal pulp is infiltrated by inflammatory cells } \\
\end{array}$
\end{tabular}

Each histomorphologic section was scored from $1-4$, with 4 representing the most desired result and 1 representing the least desired result. ${ }^{25,32}$

Collected data was analyzed using Statistical Package for Social Science (SPSS-24 version). Descriptive analysis (cross tabulation) using Chisquare test was applied to compare the histological outcome following application of MTA, Biodentine and Portland cement when $p$ value $<.05$ was considered statistically significant.

\section{Results}

Histologically, all the three tested materials produced immediate pulpal tissue reaction;ranging from acute (as was defined due to presence of granulocytes namely neutrophils, eosinophils, and basophils, the primary cells of acute inflammation) to chronic (as was defined due to presence of monocytes and lymphocytes, the primary cells of chronic inflammation) or both(as was defined due to presence of granulocytes, monocytes and lymphocytes, the primary cells of acute and chronic inflammation respectively) (figure 1$){ }^{34}$

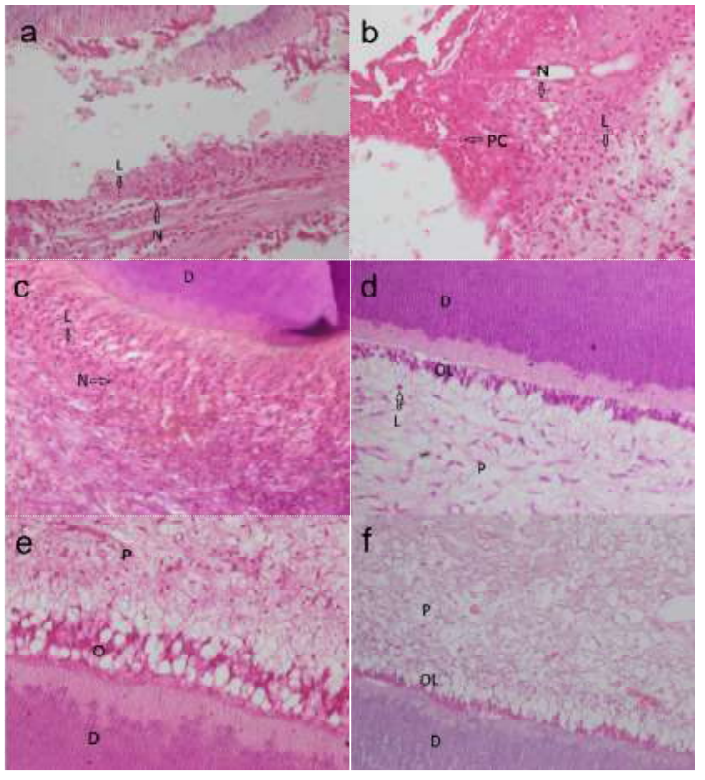

Figure 1: Pulp capping with MTA (a), Biodentin (b) and Portlan Cement (c) showing severe inflammation (defined as an average $>$ 25 inflammatory cells/HPF) as both acute and chronic inflammatory cells (granulocytes \& monocytes) infiltrating all the coronal pulp (Original magnification X 40). Whereas Mild inflammation (defined as an average $<10$ inflammatory cells /HPF) is noticed in MTA pulp caping (d) with only chronic inflammatory cells infiltrating next to area of pulp exposure. (Original magnification X 40). But no inflammation (as because of absence of any inflammatory cells) in seen in MTA Pulp capping (e) and Portland Cement Pulp capping (f) (Original magnification X 20). D, Dentin; L, lymphocytes; N, Neutrophil; O/OL, Odontoblast layer; P, Pulp; PC, Plasma cell 
'Biodentine' found to be most pulpal tissue reactive as because it produced inflammation, either acute or chronic, in every case $(100 \%)$ treated by this material (table III).

But 'Portland Cement' showed least immediate tissue reaction, in only $30 \%$ cases there was inflammation in response to 'Portland Cement' when used as pulp capping material; Whereas, there was inflammation in only $50 \%$ cases of pulp capping by MTA (table III). Mild (10\%) to moderate $(20 \%)$ to severe $(20 \%)$ grade inflammation is also seen in $50 \%$ cases of MTA pulp capping (table IV); among them in 20\% cases pulp was invaded by both acute \& chronic and in $30 \%$ cases only by chronic inflammatory cells (table III). In responded cases (a total of $50 \%$ ) of MTA pulp capping, $30 \%$ cases inflammatory cells were mostly restricted to the exposure site, in rest cases they invaded partly $(10 \%)$ or all of the coronal pulp $(10 \%)$ (table V).

Table III: Distribution of type of pulp inflammation (as defined by the presence of inflammatory cell type) in response of experimental pulp capping agents

\begin{tabular}{|c|c|c|c|c|c|c|c|}
\hline \multirow[b]{2}{*}{ Type of pulp inflammation } & \multicolumn{4}{|c|}{ Group } & \multicolumn{3}{|c|}{$\begin{array}{c}p \text { value }(<0.05 \text { is } \\
\text { significant) }\end{array}$} \\
\hline & $\begin{array}{c}\text { Group A } \\
\text { or MTA } \\
(n=20)(\%)\end{array}$ & $\begin{array}{l}\text { Group B or } \\
\text { Biodentin } \\
(n=20)(\%)\end{array}$ & $\begin{array}{l}\text { Group C or } \\
\text { Portland } \\
\text { Cement } \\
(n=20)(\%)\end{array}$ & $\begin{array}{l}\text { Control } \\
\text { group }\end{array}$ & $\begin{array}{l}\text { Group } \\
\text { A vs B }\end{array}$ & $\begin{array}{l}\text { Group } \\
\text { B vs C }\end{array}$ & $\begin{array}{l}\text { Group } \\
\text { A vs C }\end{array}$ \\
\hline No inflammation & $10(50)$ & $0(0)$ & $14(70)$ & $10(100)$ & \multirow{5}{*}{.001} & \multirow{2}{*}{.001} & .197 \\
\hline Inflammation (as a whole) & $10(50)$ & $20(100)$ & $6(30)$ & $0(0)$ & & & NS \\
\hline $\begin{array}{l}\text { Chronic inflammation } \\
\text { (as defined due to presence of chronic } \\
\text { inflammatory cells namely monocytes and } \\
\text { lymphocytes) }\end{array}$ & $6(30)$ & $12(60)$ & 0 & $0(0)$ & & & \\
\hline $\begin{array}{l}\text { Both acute and chronic inflammation } \\
\text { (as defined due to presence of both acute } \& \\
\text { chronic inflammatory cells) }\end{array}$ & $4(20)$ & $8(40)$ & $4(20)$ & $0(0)$ & & & \\
\hline $\begin{array}{l}\text { Acute inflammation } \\
\text { (as defined due to presence of acute } \\
\text { inflammatory cells namely neutrophils, } \\
\text { eosinophils, and basophils) }\end{array}$ & $0(0)$ & $0(0)$ & $2(10)$ & $10(100)$ & & & \\
\hline
\end{tabular}

Table IV: Distribution of intensity of pulp inflammation (as defined by average presence of inflammatory cells /HPF) among three experimental materials

\begin{tabular}{|c|c|c|c|c|c|c|}
\hline \multirow{2}{*}{$\begin{array}{l}\text { Intensity of pulp inflammation } \\
\text { (as defined by average presence of inflammatory } \\
\text { cells / HPF) }\end{array}$} & \multicolumn{3}{|c|}{ Group } & \multicolumn{3}{|c|}{$\begin{array}{l}p \text { value }(<0.05 \text { is } \\
\text { significant })\end{array}$} \\
\hline & $\begin{array}{c}\text { Group A or } \\
\text { MTA } \\
(\mathbf{n}=\mathbf{2 0})(\%)\end{array}$ & $\begin{array}{l}\text { Group B or } \\
\text { Biodentin } \\
(n=20)(\%)\end{array}$ & $\begin{array}{c}\text { Group C or } \\
\text { Portland } \\
\text { Cement } \\
(n=20)(\%)\end{array}$ & $\begin{array}{l}\text { Group } \\
\text { A vs B }\end{array}$ & $\begin{array}{l}\text { Group } \\
\text { B vs C }\end{array}$ & $\begin{array}{l}\text { Group } \\
\text { A vs C }\end{array}$ \\
\hline Absent, or very few inflammatory cells & $10(50)$ & $0(0)$ & $14(70)$ & \multirow{4}{*}{.004} & \multirow{4}{*}{.01} & \multirow{4}{*}{$\begin{array}{l}.34 \\
\text { NS }\end{array}$} \\
\hline $\begin{array}{l}\text { Mild, defined as an average of }<10 \text { inflammatory } \\
\text { cells }\end{array}$ & $2(10)$ & $4(20)$ & 0 & & & \\
\hline $\begin{array}{l}\text { Moderate, defined as an average } 10-25 \\
\text { inflammatory cells }\end{array}$ & $4(20)$ & $8(40)$ & $2(10)$ & & & \\
\hline $\begin{array}{l}\text { Severe, defined as an average }>25 \text { inflammatory } \\
\text { cells }\end{array}$ & $4(20)$ & $8(40)$ & $4(20)$ & & & \\
\hline
\end{tabular}

A similar mild (20\%) to moderate (40\%) to severe $(40 \%)$ grade inflammation seen in response to Biodentine (table IV). In majority of cases $(60 \%)$ pulpal inflammation was chronic type and only 40 $\%$ showed both acute and chronic inflammation (table III); where inflammatory cells were equally restricted to either next to the exposure site $(40 \%)$ or up to all of coronal pulp ( $40 \%$ ), only in $20 \%$ cases inflammatory cells remain up to part of coronal pulp (table V). 
Table V: Distribution of extension of pulp inflammation among three experimental materials

\begin{tabular}{|c|c|c|c|c|c|c|}
\hline \multirow[b]{2}{*}{ Extension of pulp inflammation } & \multicolumn{3}{|c|}{ Group } & \multicolumn{3}{|c|}{$p$ value ( $<0.05$ is significant) } \\
\hline & $\begin{array}{c}\text { Group A or } \\
\text { MTA } \\
(n=20)(\%)\end{array}$ & $\begin{array}{l}\text { Group B or } \\
\text { Biodentin } \\
(n=20)(\%)\end{array}$ & $\begin{array}{c}\text { Group C or } \\
\text { Portland } \\
\text { Cement } \\
(n=20)(\%)\end{array}$ & $\begin{array}{l}\text { Group } \\
\text { A vs B }\end{array}$ & $\begin{array}{l}\text { Group } \\
\text { B vs C }\end{array}$ & $\begin{array}{l}\text { Group } \\
\text { A vs C }\end{array}$ \\
\hline Absent & $10(50)$ & $0(0)$ & $14(70)$ & & & \\
\hline $\begin{array}{l}\text { Mild, defined as inflammatory cells only } \\
\text { next to area to pulp exposure }\end{array}$ & $6(30)$ & $8(40)$ & 0 & & & \\
\hline $\begin{array}{l}\text { Moderate, defined as inflammatory cells } \\
\text { observe in part of coronal pulp } \\
\text { inflammatory cells }\end{array}$ & $2(10)$ & $4(20)$ & $6(30)$ & .002 & .01 & .014 \\
\hline $\begin{array}{l}\text { Severe, defined as all coronal pulp is } \\
\text { infiltrated }\end{array}$ & $2(10)$ & $8(40)$ & $0(00)$ & & & \\
\hline
\end{tabular}

In those cases, where (only $30 \%$ ) Portland cement showed pulpal tissue reaction, ranging from moderate to severe (table IV); among them in $20 \%$ cases pulp was invaded by both acute \& chronic inflammatory cells and in $10 \%$ cases only by acute cells (table III). In all the cases, inflammatory cells were restricted up to part of coronal pulp (table V).

Type of immediate pulpal tissue reaction in response to tested material found to be statistically significant different between 'Biodentine' and 'Portland cement' $(p=0.001)$, also between 'Biodentine' and 'MTA' and $(p=0.001)$; but there was no statistically significant difference between 'MTA' and 'Portland cement' $(p=0.197)$ (table III).

Considering intensity of inflammation, there was statistically significant difference in between Biodentine and Portland cement $(p=0.01)$. Whereas, MTA differed statistically in relation to Biodentine $(p=0.004)$ but MTA didn't differ statistically in relation to Portland cement ( $p$ $=0.34$ ) (table IV).

Similarly, considering the extension of inflammatory cells, there was statistically significant difference in between Biodentine and MTA $(p=0.002)$, also between Biodentine and Portland cement $(p=0.01)$. Furthermore, MTA showed statistically significant difference with Portland cement $(p=0.014)$ (table V).

\section{Discussion}

In the present study, pulpal inflammation found against all the tested material which are consistent with the findings of Herrero de Morais et alwho observed moderate to severe inflammatory response in response to MTA and Portland cement pulp capping after a period of 7 days. ${ }^{35}$ Zarrabi et alalso found inflammation of the pulp against MTA and Novel Endodontic Cement (NEC) after a gradual observation period of 2 weeks and 8 weeks. ${ }^{4}$ But present study differs with the findings of Nowicka et al where an absence of or few inflammatory cells were observed in a majority of pulp specimens when human dental pulp capped with Biodentin and MTA. ${ }^{25}$ The difference between inflammatory pulpal response is probably due to time frame of evaluation; we observed pulpal response only after 24 hours whereas they observed after 6 weeks, when the inflammation is ultimately subsided other than presence of few concentrated collagen fibers and congested blood vessels as the descent of chronic inflammation in 3 teeth in the Biodentine group and 2 teeth in the MTA group. The change in the nature of pulpal response (inflammation) to any material on passing of time is justified by the study of Zarrabi et al who found gradual decrease in inflammation in their study specimen from 2 weeks to 8 weeks. ${ }^{4}$ When assessed after 2 weeks, $62.5 \%$ of the MTA and $50 \%$ of the NEC samples showed mild to moderate inflammation; whereas inflammation reduced to $25 \%$ in MTA samples and $12.5 \%$ in NEC samples after 8 weeks. ${ }^{4}$ There was a significant difference regarding pulp response to MTA and NEC between the observation period 2 weeks and 8 weeks. Similarly, by the study of Menezes et alall the samples (76 in no) capped with MTA and Portland cement, pulp tissue was normal and free of inflammatory cells other than a discrete presence of macrophages in some cases after a period of 16 weeks. ${ }^{36}$ 
In the this study, Biodentine showed significantly more immediate pulpal response compared to MTA in view of type, intensity and extension of pulpal inflammation. But previous study found no difference in the pulpal inflammatory response against these two pulp capping materials; which may be due to the time frame of evaluation as discussed earlier. ${ }^{22}$ However more immediate pulpal tissue response by Biodentine than that of MTA may result ultimate difference in future as found by De Rossi et alin his study dentin bridges formed by Biodentin and MTA at the amputation site had similar morphology, but they were significantly thicker in the Biodentine group. ${ }^{37}$

Similarly, the Biodentine showed statistically significant more immediate pulpal response compared to Portland cement in view of type, intensity and extension of pulpal inflammation. We didn't found any previous study comparing pulpal response to Biodentine and Portland cement but our findings may be justified by the other published studiesin which inflammatory response to PC was compared with that of MTA and no significant difference observed between MTA and Portland cement. ${ }^{36,37}$ Because present study concluded that MTA and Portland cement showed more or less similar pulpal response in view of type, intensity and extension of pulpal inflammation and there was no statistically significant difference, So the behavior of Biodentin to MTA and Portland cement should be similar as observed in the present study.

Presence of both acute and chronic inflammation or only chronic inflammation only after 24 hours as found in this study, is consistent with the inherrent chemotactic characteristics of the different types of white blood cells during inflammation. It has been stablished that the nature of the leukocyte infiltrate varies with the age of the inflammatory response and the type of stimulus. Neutrophils those are usually neumerous in blood, predominates in most form of acute inflammation during the first 6 to 24 hours and are replaced by monocytes in 24 to 48 hours. Other than some pseudomonas bacterial infection, in which situation neutrophils continuously recruited for several days, they usually undergo apoptosis and disappear within 24 to 48 hours, while lymphocytes may be the first cells to arrive as well as dominating cells in some hypersensitivity reaction. Monocytes not only survive longer but also proliferate in the tissues and thus become the dominant population in case of prolonged inflammatory reactions. ${ }^{38}$

Finally, Biodentin showed more immediate pulpal tissue reactivity than MTA and portland cement while previous study revealed that biodentin produces more thicker dentin bridge than MTA. ${ }^{37}$ Thus our resultsconfirms the link suggested in previous studythat inflammatory processes has definite contribution in producing a reparative dentinal bridge for closing the pulp exposure. ${ }^{27,28}$

It may be mentioned that the present study was performed on normal healthy pulps. Therefore, these results do not necessarily reflect what will happen if they are used on inflamed pulps. Therefore, the authors suggest that further assessment is required for evaluation of pulp response to these pulp capping materials in inflamed pulp.

\section{Conclusion}

According to present study biodentin is found to be most immediate pulpal tissue reactive and it showed immmediate reactivity (inflammation) in all cases, MTA was the next and portland cement found the least immediate tissue reactive when used as a pulp capping material.

Conflict of Interest:The authors declare no conflict of interest related to this study.

\section{Reference}

1. Parirokh M, Asgary S, Eghbal MJ, Kakoei S, Samiee M. A comparative study of using a combination of calcium chloride and mineral trioxide aggregate as the pulp-capping agent on dogs' teeth. J Endod. 2011; 37:786-88.

2. Laurent P, Camps J, About I. Biodentine induces TGF-b1 release from human pulp cells and early dental pulp mineralization. Int Endod J. 2012; 45:439-48.

3. Zanini M, Sautier JM, Berdal A, Simon S. Biodentine induces immortalized murine pulp cell differentiation into odontoblast-like cells and stimulates biomineralization. J Endod. 2012; 38:1220-26.

4. Zarrabi MH, Javidi M, Jafarian AH, Joushan B. Immunohistochemical expression of fibronectin and tenascin in human tooth pulp capped with mineral trioxide aggre-gate and a novel endodontic cement. J Endod. 2011; 37:1613-18.

5. Qureshi A, Soujanya E, Kumar N, Kumar P, Rao S. Recent Advances in Pulp Capping Materials: 
An Overview. Journal of Clinical and Diagnostic Research. 2014; 8:316-321

6. Alex G. Direct and Indirect Pulp capping: A brief history, Material Innovations, and Clinical Case Report. 2018; 39:182-189

7. Lee YL, Wang WH, Lin FH, Lin CP. Hydration behaviors of calcium silicate-based biomaterials. Journal of the Formosan Medical Association. 2017 ; 116:424-31

8. Morotomi T, Washio A,Kitamura C.Current and future options for dental pulp therapy Jpn Dent Sci Rev. 2019; 55:5-11.DOI: 10.1016/j.jdsr.2018.09.001

9. Aqrabawi J. Sealing ability of amalgam, super EBA cement, and MTA when used as retrograde filling materials. Br Dent J. 2002; 188:266-68.

10. Holland R, de Souza V, Murata SS, Nery MJ, Bernabé PF, Otoboni Filho JA. Healing process of dog dental pulp after pulpotomy and pulp covering with mineral trioxide aggregate or Portland cement. Braz Dent J. 2001;12:109-13.

11. Parirokh $\mathrm{M}$, Torabinejad $\mathrm{M}$. Mineral Trioxide Aggregate: A Comprehensive Literature ReviewPart III: Clinical Applications, Drawbacks, and Mechanism of Action. JOE. 2010; 36:400-413

12. Min KS, Park HJ, Lee SK, Kim EC. Effect of Mineral Trioxide Aggregate on Dentin Bridge Formation and Expression of Dentin Sialoprotein and Heme Oxygenase-1 in Human Dental Pulp. Journal of endodontics. 2008; 34:666-70

13. Al-Hezaimi K, Al-Tayar BA, Bajuaifer YS, Salameh Z, Al-Fouzan K, Tay FR. A hybrid approach to direct pulp capping by using emdogain with a capping material. J. Endod. 2011; 37:667-72.

14. Mehrvarzfar P, Abbot PV, Mashhadiabbas F, Vatanpour M, Savadkouhi ST. Clinical and histological responses of human dental pulp to MTA and combined MTA/treated dentin matrix in partial pulpotomy. Aust Endod J. 2018; 44:46-53

15. Hajizadeh N, Madani ZS, Zabihi E, Golpour M, Zahedpasha A, Mohammadnia M. Effect of MTA and CEM on Mineralization-Associated Gene Expression in Stem Cells Derived from Apical Papilla Iranian Endodontic Journal. 2018;13:94-101

16. Yuan Z, Peng B, Jiang H, Bian Z, Yan P. Effect of bioaggregate on mineral-associated gene expression in osteoblast cells. J Endod. 2010; 36:1145-8

17. Camilleri J. Characterization of hydration products of mineral trioxide aggregate. International Endodontic Journal. 2008; 41:408-417
18. Sakai VT, Moretti AB, Oliveira TM, Fornetti AP, Santos CF, Machado MA, et al. Pulpotomy of human primary molars with MTA and Portland cement: a randomised controlled trial. Br Dent J. 2009; 207:E5.

19. Estrela C, Bahmann LL, Estrela CRA, Silva RS, Pe'cora JD. Antimicrobial and chemical study of MTA, Portland cement, calcium hydroxide paste, Sealapex and Dycal. Braz Dent J. 2000; 11:19-27.

20. Funteas UR, Wallace JA, Fochtman EW. A comparative analysis of mineral trioxide aggregate and Portland cement. Aust Endod J. 2003; 29:43-44

21. Hungaro Duarte MA, de Oliveira El Kadre GD, Vivan RR, Guerreiro Tanomaru JM, Tanomaru Filho M, de Moraes IG. Radiopacity of portland cement associated with different radiopacifying agents. Journal of Endodontics. 2009; 35:737-40

22. Min KS, Kim HI, Park HJ, Pi SH, Hong CU, Kim EC. Human pulp cells response to Portland cement in vitro. Journal of Endodontics. 2007; 33:163-66.

23. Abdullah D, Pitt Ford $\mathrm{T}$, Papaioannou $\mathrm{S}$, Nicholson J, McDonald F. An evaluation of accelerated Portland cement as a restorative material. Biomaterials. 2002; 23:4001-10.

24. Bortoluzzi EA, Broon NJ, Bramante CM, Consolaro A, Garcia RB, de Moraes IG, et al. Mineral trioxide aggregate with or without calcium chloride in pulpotomy. J Endod. 2008; 34:172-75.

25. Nowicka A, Lipski M, Parafiniuk M, SporniakTutak K, Lichota D, Kosierkiewicz A, et al. Response of human dental pulp capped with biodentine and mineral trioxide aggregate. Journal of Endodontics. 2013;39:743-47

26. Tran XV, Gorin C, Willig C, Baroukh B, Pellat B, Decup F, et al. Effect of a calcium-silicate-based restorative cement on pulp repair. J Den Res. 2012; 91:1166-71.

27. Goldberg M, Njeh A, Uzunoglu E. Is Pulp Inflammation a Prerequisite for Pulp Healing and Regeneration? Hindawi Publishing Corporation Mediators of Inflammation Volume 2015, Article ID 347649,11 . DOI: $10.1155 / 2015 / 347649$

28. Goldberg M, Farges JC, Lacerda-Pinheiro S, Six N, Jegat N, Decup F, Septier D, Carrouel F, Durand S, Chaussain-Miller C, DenBesten P, Veis A, Poliard A. Inflammatory and immunological aspects of dental pulp repair. Pharmacological Research. 2008; 58:137-147.

29. Schr"oder U. Effects of calcium hydroxidecontaining pulp capping agents on pulp cell 
migration, proliferation, and differentiation. Journal of Dental Research. 1985; 64:541-48.

30. Soares IML. Respostapulparao MTA-agregado de trio'xido mineral-comparadoaohidro'xido de ca'lcioempulpotomias. Histolo' gicoemdentes de cães. Florianopolis, SC, Brazil: Faculdade de Odontologia, Universidade Federal de Santa Catarina. 1996

31. Accorinte MR, Reis A, Sueli S. Murata, Alessandro LD. Evaluation of Mineral Trioxide Aggregate and Calcium Hydroxide Cement as Pulp-capping Agents in Human Teeth. JOE. 2008; 34:1-6

32. Faraco IM Jr, Holland R. Response of the pulp of dogs to capping with mineral trioxide aggregate or a calcium hydroxide cement. Dent Traumatol. 2001; 17:163-66.

33. Medina VO, $3^{\text {rd }}$, Shinkai K, Shirono M, Tanaka N, Katoh Y. Histopathologic study on pulp response to single-bottle and self-etching adhesive systems. Oper Dent. 2002; 27:330-42.

34. Cobanoglu N, Ozer F, Demirci M, Ozdemir O, Imazato S. Histopathological evaluation of human pulp response to two self-etching resins. Journal of Restorative Dentistry. 2015; 3:1-7
35. Herrero de Morais CA, Bernardineli N, Garcia RB, Duarte MAH, Guerisoli DMZ. Evaluation of tissue response to MTA and Portland cement with iodoform. Oral Surg Oral Med Oral Pathol Oral RadiolEndod. 2006; 102:417-21

36. Menezes R, Bramante CM, Letra A, Carvalho VGG, Garcia RB. Histologic evaluation of pulpotomies in dog using two types of mineral trioxide aggregate and regular and white Portland cements as wound dressings. Oral Surg Oral Med Oral Pathol Oral RadiolEndod. 2004; 98:376-79.

37. De Rossi A, Silva LA, Gatón-Hernández P, SousaNeto MD, Nelson-Filho P, Silva RA, et al. Comparison of Pulpal Responses to Pulpotomy and Pulp Capping with Biodentine and Mineral Trioxide Aggregate in Dogs. Journal of Endodontics. 2014; 40:1362-69.

38. Kumar V, Abbas Ak editors Robbins and cotranpathologicbasis of diseases, $9^{\text {th }}$ edition, Elsevier Saunders, Philadelphia, PA 2015; P-77 